\title{
Synthetic Studies on Diels-Alder Adducts: Intramolecular Interactions Between Two Functions
}

\author{
Mauricio Gomes Constantino*, Altamiro Xavier de Souza and Gil Valdo José da Silva \\ Departamento de Química, Faculdade de Filosofia, Ciências e Letras de Ribeirão Preto, Universidade \\ de São Paulo, Av. Bandeirantes 3900, 14040-901 - Ribeirão Preto - SP, Brazil. Phone +55/16 602 \\ 3747. Fax +55/16 6338151 .
}

*Author to whom correspondence should be addressed; e-mail: mgconsta@usp.br

Received: 17 August 2001; in revised form: 28 June 2002 / Accepted: 28 June 2002 / Published: 30 June 2002

\begin{abstract}
In this paper we describe the synthesis of a $\gamma, \delta$-unsaturated aldehyde from a bicyclic Diels-Alder adduct, to be used in future electrocyclic reaction studies. A number of reactions produced undesired materials resulting from the interaction between functions, forcing the use of partial protection to accomplish a synthesis that would be otherwise straightforward. Suggestions to account for the results are given.
\end{abstract}

Keywords: Diels-Alder adducts, Intramolecular interactions, 1,4-Diols oxidation, Cyclic phosphite

\section{Introduction}

During our studies on the preparation of polycyclic compounds through the Diels-Alder reactions we have faced a circumstance of unusual recurrence of interference between two functions existing in the same molecule, resulting in changes of the properties usually associated with each function and giving rise to unexpected and rather surprising results.

In our view, it is essential to improve the systematization of knowledge about interferences between functions, thus bringing higher reliability to organic syntheses projects. The results disclosed 
in this paper, for instance, confirm that some 1,4-diols cannot be easily oxidized to 1,4-dialdehydes due to a strong tendency towards formation of a lactol, which blocks further oxidation with common reagents. In these cases it is necessary to make use of partial protections, thus preventing one (protected) function to interfere in the properties of the other (unprotected) one. It is also possible to make a direct transformation through the use of special reagents [1].

Seeking the development of synthetic methods for the preparation of annulenes [2] and heliangolides [3] through the Diels-Alder reaction, our aim in this work [4] was the preparation of compound 2, from 1, for use in electrocyclic reactions studies (Scheme 1).

\section{Scheme 1}<smiles>OC[C@H]1C2C=CC(C2)[C@H]1CO</smiles>

1

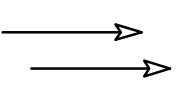

2a: $\mathrm{R}=\mathrm{CHO}$

2b: $\mathrm{R}=-\mathrm{CH}=\mathrm{CH}_{2}$

This is an apparently a very simple transformation, as it would require only the oxidation of the diol to a dialdehyde and a Wittig reaction, using $\mathrm{Ph}_{3} \mathrm{P}=\mathrm{CH}_{2}$, with one or both aldehyde groups. The starting material 1 can be easily prepared by Diels-Alder reaction between cyclopentadiene and maleic anhydride, followed by reduction (Scheme 2) [5].

Scheme 2

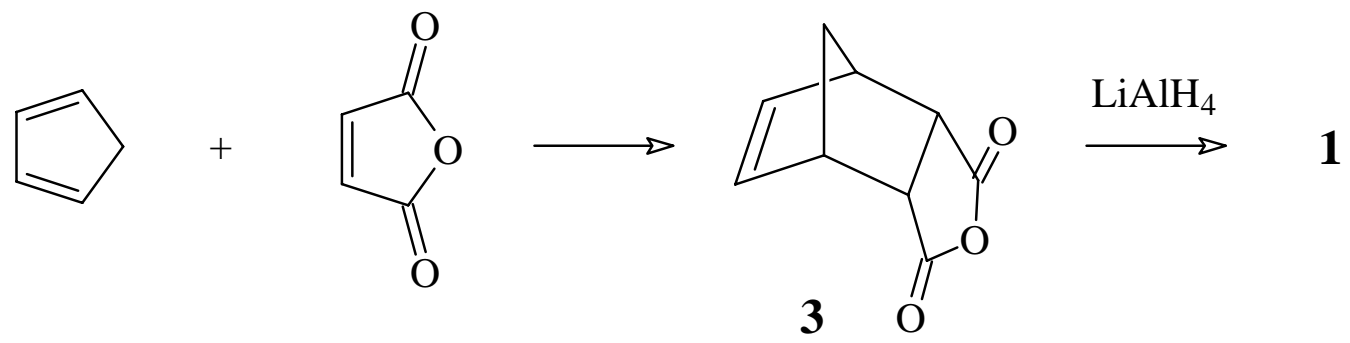

However, the oxidation of 1,4-diols to 1,4-dialdehydes is not an easily accomplishable transformation, as these diols usually give lactols or lactones [6] upon treatment with oxidizing reagents (see, however, reference [1]). The use of $o$-iodoxybenzoic acid in DMSO to oxidize 1,4-diols to lactols has recently been proposed [7], the transformation of 1 into $\mathbf{4}$ (Scheme 3) being one of the examples used by the authors. In exploratory experiments we have confirmed that only lactol $\mathbf{4}$ is obtained when $\mathbf{1}$ is treated with a number of oxidizing reagents; two examples are mentioned in Scheme 3 . 


\section{Scheme 3}

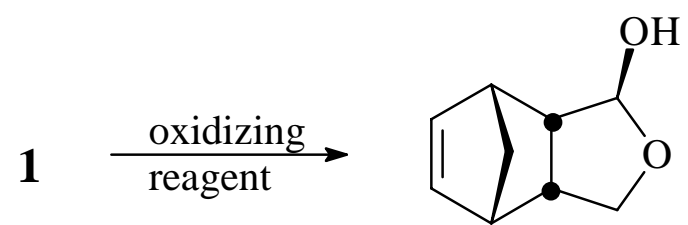

4

Reagent / solvent

Yield

\begin{tabular}{ll}
\hline$o$-iodoxybenzoic acid in DMSO & $82 \%$ (ref. 7) \\
PDC in $\mathrm{CH}_{2} \mathrm{Cl}_{2}$ & $60 \%$ \\
Dess-Martin Periodinane in $\mathrm{CH}_{2} \mathrm{Cl}_{2}$ & $66 \%$
\end{tabular}

These results show that, as soon as one of the $\mathrm{CH}_{2} \mathrm{OH}$ groups is oxidized (or even during the oxidation), the other $-\mathrm{OH}$ attacks the carbonyl group, forming the stable lactol $\mathbf{4}$ and preventing the oxidation of the second alcohol group. The obvious solution to this kind of problem is to protect one of the $-\mathrm{OH}$ groups and make the desired transformations on the other. However, before following this distended route (described ahead), we decided to try a smaller modification in the same method, just interchanging carbonyl group and phosphorane in the Wittig reaction: diol $\mathbf{1}$ could be transformed into the corresponding dibromo compound, and this into the di-Wittig reagent, which would be treated with formaldehyde.

Treatment of 1 with $\mathrm{PBr}_{3}$, however, led to a surprising result: after hydrolysis and extraction, a phosphite of the diol was obtained as a mixture of stereoisomers that were separated by column chromatography (compounds $\mathbf{7 a}$ and $\mathbf{7 b}$ ). The transformation of an alcohol into the corresponding bromide with $\mathrm{PBr}_{3}$ normally involves the initial formation of phosphites [8] such as 5, 6 (Scheme 4) or trialkyl phosphites, that undergo a $\mathrm{C}-\mathrm{O}$ bond breaking and simultaneous or successive $\mathrm{C}-\mathrm{Br}$ bond formation.

\section{Scheme 4}

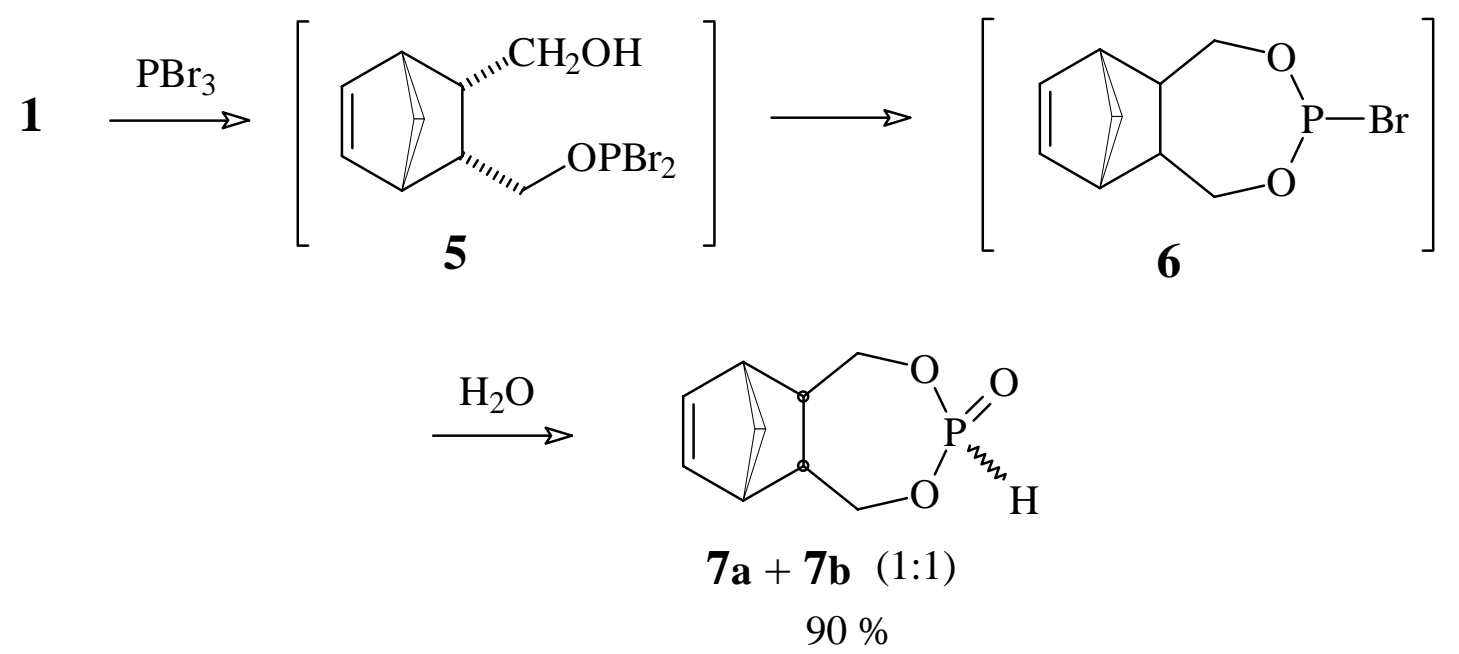


The final result of this reaction suggests that intermediate $\mathbf{5}$ has been fully transformed into intermediate $\mathbf{6}$ and no further reaction occurred; hydrolysis during extraction resulted in the formation of cyclic phosphites $\mathbf{7}$. The unusual structures of compounds $\mathbf{7 a}$ and $\mathbf{7 b}$ was first suggested by the occurrence, in their ${ }^{1} \mathrm{H}$-NMR spectra, of doublets corresponding to one hydrogen each in $6.71 \delta$ (7a) and $6.73 \delta(7 \mathbf{b})$ with very large coupling constants $(725 \mathrm{~Hz}$ for $7 \mathbf{a}$ and $660 \mathrm{~Hz}$ for $\mathbf{7 b})$, values observed only when a P-H bond is present [9]. The ${ }^{13} \mathrm{C}-\mathrm{NMR}$ spectra of these compounds also show doublets for the methylene carbons $\left(\mathrm{CH}_{2} \mathrm{O}\right)$ corresponding to coupling between these methylene carbons and the phosphorus atom with normal $\mathrm{J}$ values [10] for this type of structure (6.9 Hz for $\mathbf{7 a}$ and $5.1 \mathrm{~Hz}$ for $\mathbf{7 b}$ ). Further confirmation of these structures is given by the ${ }^{31} \mathrm{P}-\mathrm{NMR}$ spectra. As shown in Figures $\mathbf{1}$ and 2, each of these spectra contains a double triple triplet with the same $J$ values found in the corresponding ${ }^{1} \mathrm{H}-\mathrm{NMR}$ spectra. Obviously, the coupling between phosphorus and carbon cannot be seen in these spectra due to the low abundance of the ${ }^{13} \mathrm{C}$ isotope.

Figure 1. ${ }^{31} \mathrm{P}$ NMR spectrum of $7 \mathbf{a}$

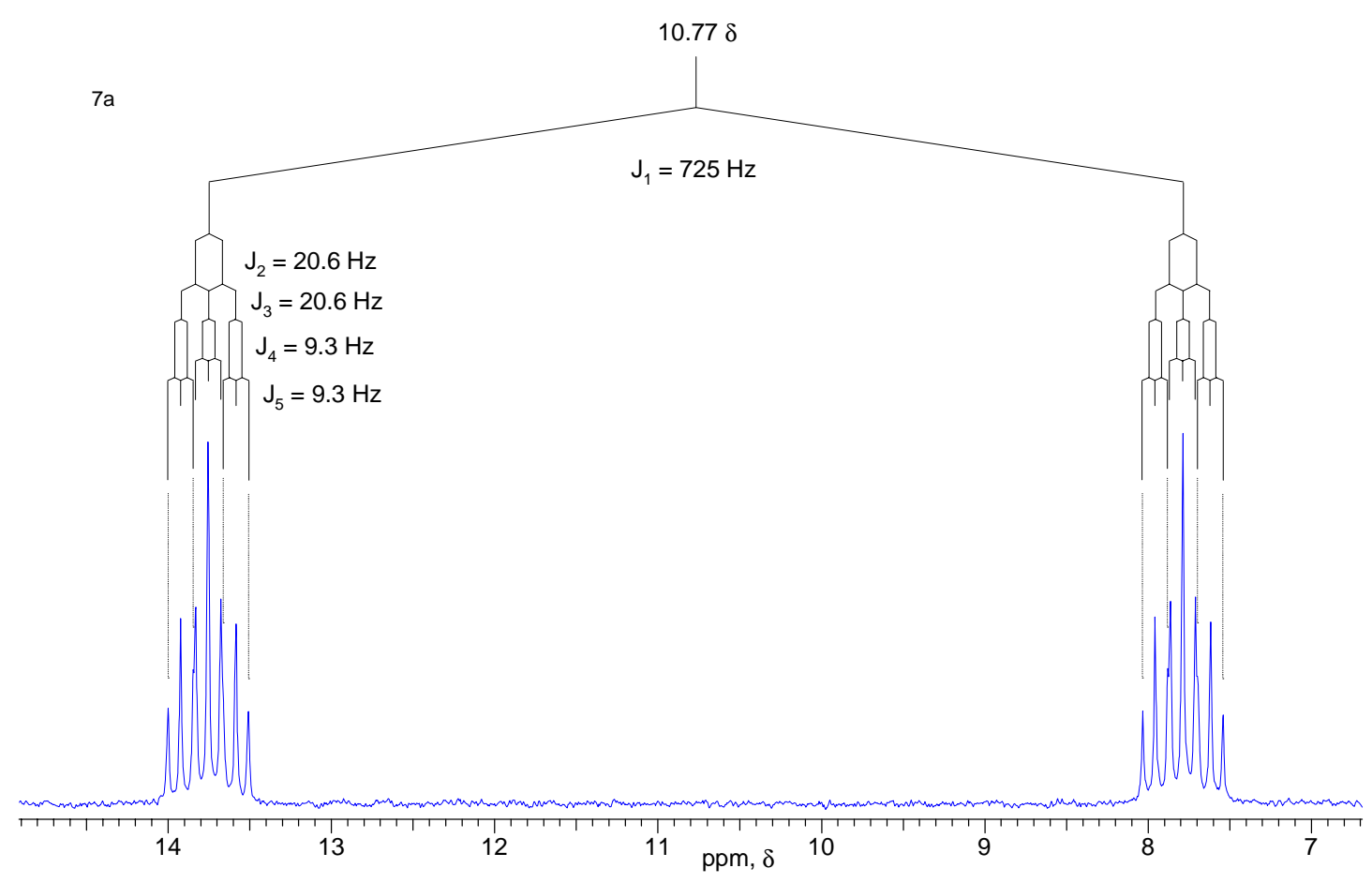

It is clear, from the data we have collected until now, that compounds $\mathbf{7 a}$ and $\mathbf{7 b}$ are stereoisomers differing by the relative stereochemistry at the phosphorus atom; however, we could not yet assign the corresponding stereochemistry to each isomer. Further studies with this purpose are presently in course. 
Figure 2. ${ }^{31} \mathrm{P}$ NMR spectrum of $\mathbf{7 b}$

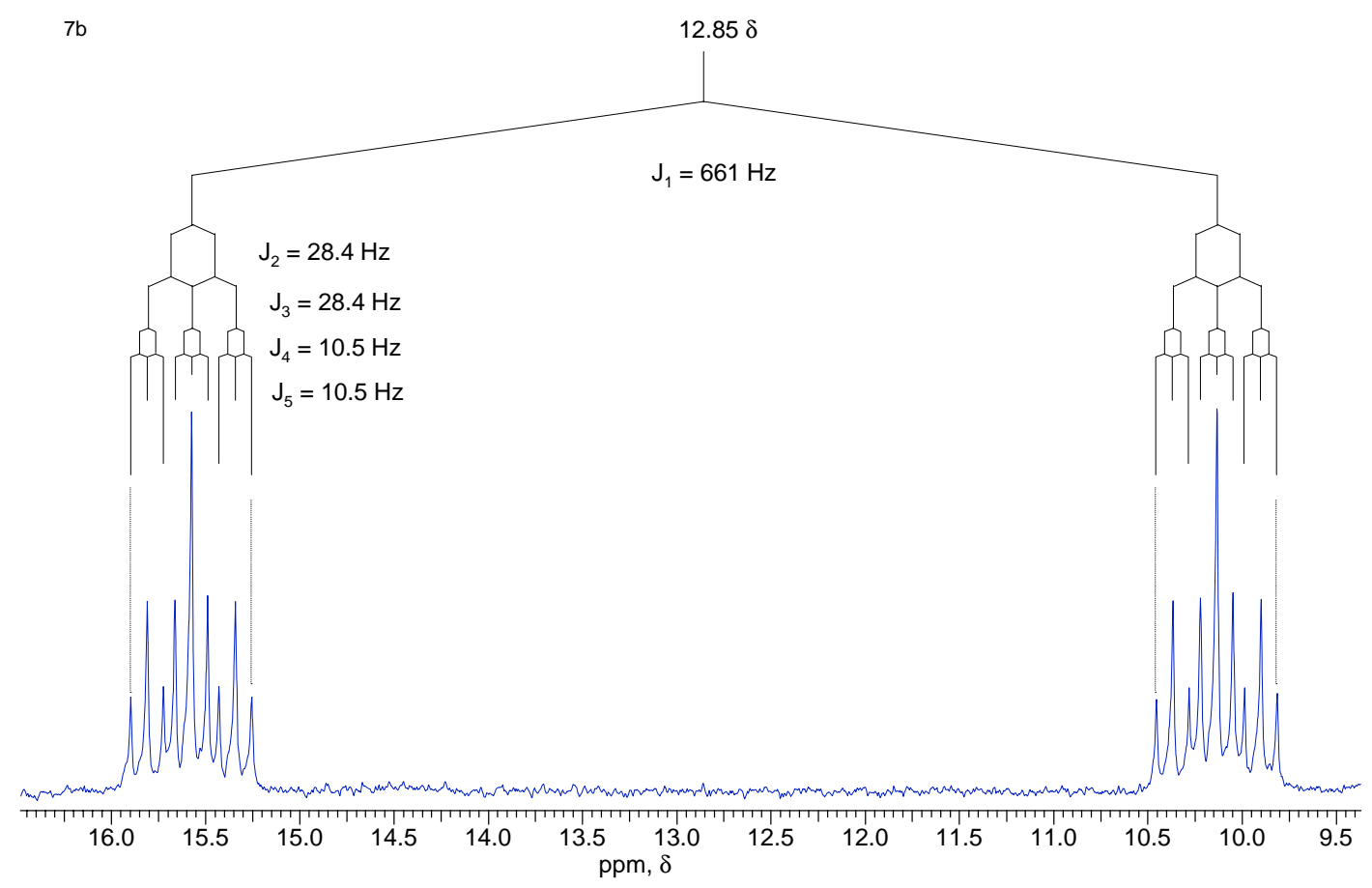

The two cases of interactions just discussed, resulting in formation of $\mathbf{4}$ and of $\mathbf{7}$,respectively, however similar, are not quite the same. To some extent, the formation of lactol $\mathbf{4}$ could be considered as a foreseeable result, because a 5-membered ring is formed, a transformation usually favored both kinetically and thermodynamically (entropy playing a very important role here); on the other hand, this doesn't seem to be the case of compound 7, as 7-membered rings are not as easily formed. We should remark, however, that this is a special type of 7-membered ring: it contains two oxygen atoms (which, contrary to the usual carbon atom case, have no substituents, thus reducing transannular interactions) and two strong P-O bonds. Similar compounds, also containing 7-membered rings, have been previously reported [11].

Through the use of partial protection it was possible to realize the desired transformations. Compound $\mathbf{1}$ was converted to the monoprotected compound $\mathbf{8}$. By using the technique of transforming the alcohol into an alcoxide before adding the electrophile, the formation of the diprotected compound $\mathbf{9}$ was reduced to a minimum, due to the low tendency towards dianion formation (Scheme 5).

Scheme 5

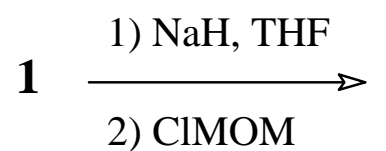<smiles>COC[C@H]1[C@H]2C=C[C@@H](C2)[C@H]1CO</smiles>

8

$67 \%$<smiles>COC[C@H]1[C@H]2C=CC(C2)[C@H]1COC</smiles>

9 $<1 \%$ 
The subsequent transformations gave the expected results (Scheme 6): oxidation of the free alcohol of 8 with PDC to produce the aldehyde in $60 \%$ yield, a Wittig reaction giving olefin $11(77 \%)$ and deprotection of the alcohol (59\%). Compound $\mathbf{1 2}$ is rather unstable, and had to be kept in benzene solution with a small amount of hydroquinone to prevent decomposition during storage.

\section{Scheme 6}

$8 \underset{\mathrm{CH}_{2} \mathrm{Cl}_{2}}{\stackrel{\mathrm{PDC}}{\longrightarrow}}$

$60 \%$<smiles>COC[C@H]1[C@H]2C=C[C@@H](C2)[C@H]1C=O</smiles>

10

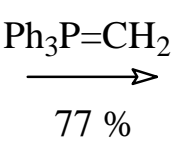

$77 \%$<smiles>C=C[C@H]1[C@H]2C=CC(C2)[C@H]1COC</smiles>

11
$\underset{\mathrm{H}_{2} \mathrm{O} / \mathrm{MeOH}}{\stackrel{\mathrm{HCl}}{\longrightarrow}}$

$59 \%$<smiles>C=C[C@H]1C2C=CC(C2)[C@@H]1CO</smiles>

12
$\underset{\mathrm{CH}_{2} \mathrm{Cl}_{2}}{\stackrel{\mathrm{PDC}}{\longrightarrow}}$

$2 \mathbf{a}$ $57 \%$

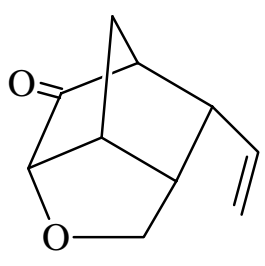

13

$5 \%$

The last step, oxidation of $\mathbf{1 2}$ with PDC, gave the desired product 2a (57\% yield) together with a small amount of the by-product 13 (5\% yield), again an evidence of interference between two functions. The formation of compound $\mathbf{1 3}$ could be rationalized by at least two different ways, as depicted in Scheme 7.

\section{Scheme 7}

a)

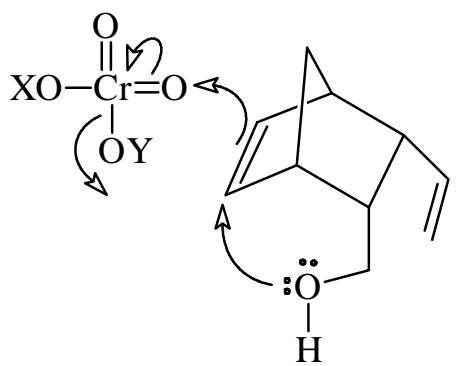

12

b)

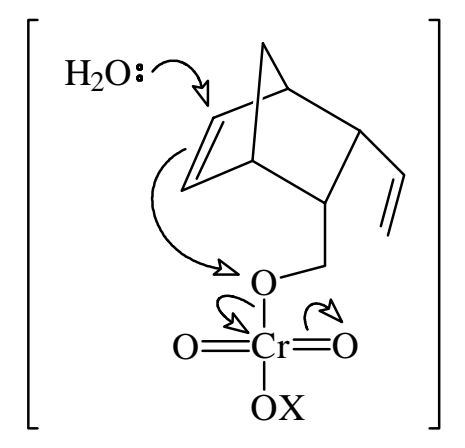<smiles></smiles>

14

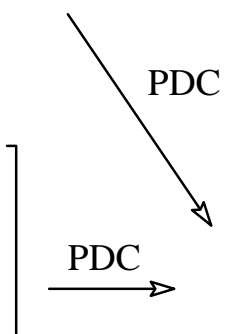


According to hypothesis (a), the chromate reagent attacks the double bond (and not the alcohol), whose reactivity could be enhanced by influence of the $-\mathrm{OH}$ group, resulting in the intermediate 14; this would be either hydrolyzed to $\mathbf{1 6}$ and then oxidized to $\mathbf{1 3}$, or would be directly oxidized to $\mathbf{1 3}$, more likely via reaction with $\mathrm{Cr}$ (VI). In hypothesis (b), the normal intermediate for this kind of oxidation (15) [8] would be formed first but, instead of the normal abstraction of the hydrogen $\alpha$ to the $-\mathrm{OH}$ group, a nucleophillic attack of the double bond (possibly assisted by water) would take place, resulting in the same intermediate 16. In any case it is obvious that the formation of compound $\mathbf{1 3}$ is a result of the proximity and the resulting interactions between the double bond and the $-\mathrm{OH}$ group in compound 12.

\section{Conclusions}

The relatively simple synthesis of compound 2a here described shows the importance of taking into account the intramolecular interactions between two functions, even in simple molecules, and how valuable the use of protective groups can be to overcome this sort of problems. The ease of formation and the stability of 5-membered ring lactols is remarkable, as well as the surprising formation of the cyclic phosphite 7. As compound $\mathbf{1 3}$ is formed in only $5 \%$ yield, this reaction is obviously less important. However, it is a further evidence of how close to each other are the functions in these DielsAlder adducts, and how important this aspect can be when designing organic syntheses.

\section{Acknowledgments}

The authors thank the Fundação de Amparo à Pesquisa do Estado de São Paulo (FAPESP), the Conselho Nacional de Desenvolvimento Científico e Tecnológico (CNPq) and the Coordenadoria de Aperfeiçoamento de Pessoal do Ensino Superior (CAPES) for financial support.

\section{Experimental section}

\section{General}

NMR spectra were measured using a Bruker DPX-300 (300 MHz ${ }^{1} \mathrm{H}-\mathrm{NMR}$ and $75 \mathrm{MHz}$ ${ }^{13} \mathrm{C}-\mathrm{NMR}$ ) or DRX-400 (400 MHz ${ }^{1} \mathrm{H}-\mathrm{NMR}$ and $100 \mathrm{MHz}{ }^{13} \mathrm{C}-\mathrm{NMR}$ ) instruments; deuterochloroform was used as solvent and tetramethylsilane as the internal standard; ${ }^{31} \mathrm{P}-\mathrm{NMR}$ spectra were measured with Bruker DPX-300 (121.5 MHz) using $\mathrm{H}_{3} \mathrm{PO}_{4} / \mathrm{D}_{2} \mathrm{O}$ as external standard. IR spectra were measured with a Perkin-Elmer 1600-FT or Nicolet 5ZDX spectrometers. TLC was performed on precoated silica gel $60 \mathrm{~F}_{254}$ plates $(0.25 \mathrm{~mm}$ thick, Merck), and for column chromatography silica gel 60 70-230 mesh (Merck) was used. Reported yields refer to samples with the same purity as the samples used in the following step. 


\section{4-Oxatricyclo[5.2.1.0 $\left.{ }^{2,6}\right]$ dec-8-en-3-ol (4)}

a) Oxidation with PDC. To a solution of pyridinium dichromate $(3.0 \mathrm{~g}, 8.0 \mathrm{mmol})$ in anhydrous $\mathrm{CH}_{2} \mathrm{Cl}_{2}$ (30 mL), maintained under $\mathrm{N}_{2}$ atmosphere, was added a solution of compound $\mathbf{1}$ (640 mg, 4.1 mmol) in $\mathrm{CH}_{2} \mathrm{Cl}_{2}(10 \mathrm{~mL})$. After stirring for $24 \mathrm{~h}$ at room temperature, the solution was filtered through a small column of $\mathrm{MgSO}_{4}$. The solvent was removed under vacuum and the residue was chromatographed in a column of silica gel using a 4:6 mixture of hexane / ethyl acetate. Yield $374 \mathrm{mg}$ $(60 \%)$.

b) Oxidation with Dess-Martin periodinane. To a solution of diol 1 (61 mg, $0.37 \mathrm{mmol})$ in anhydrous $\mathrm{CH}_{2} \mathrm{Cl}_{2}(1.2 \mathrm{~mL})$, maintained under $\mathrm{N}_{2}$ atmosphere, was added a solution of Dess-Martin periodinane [12] (351 mg, $0.80 \mathrm{mmol}$ ) in $\mathrm{CH}_{2} \mathrm{Cl}_{2}(3 \mathrm{~mL})$. After stirring at room temperature for $20 \mathrm{~min}$, the reaction mixture was diluted with ethyl ether $(10 \mathrm{~mL})$ and quenched with a $1.3 \mathrm{M}$ aqueous solution of $\mathrm{NaOH}$. After 10 min of vigorous stirring the organic phase was separated, washed with aqueous $\mathrm{NaOH}$ solution, water, and dried with $\mathrm{MgSO}_{4}$. The solvent was removed under vacuum and the residue was purified by chromatography as described in (a). Yield $37 \mathrm{mg}(66 \%)$.

Spectroscopic data: ${ }^{1} \mathrm{H}-\mathrm{NMR}\left(\mathrm{CDCl}_{3}, 400 \mathrm{MHz}\right) \delta 6.20\left(\mathrm{dd}, 1 \mathrm{H}, \mathrm{J}_{1}=5.6 \mathrm{~Hz}, \mathrm{~J}_{2}=3.0 \mathrm{~Hz}\right), 6.09(\mathrm{dd}, 1$ $\left.\mathrm{H}, \mathrm{J}_{1}=5.8 \mathrm{~Hz}, \mathrm{~J}_{2}=3.0 \mathrm{~Hz}\right), 4.98(\mathrm{~s}, 1 \mathrm{H}), 3.98\left(\mathrm{dd}, 1 \mathrm{H}, \mathrm{J}_{1}=7.6 \mathrm{~Hz}, \mathrm{~J}_{2}=8.8 \mathrm{~Hz}\right), 3.46\left(\mathrm{dd}, 1 \mathrm{H}, \mathrm{J}_{1}=\right.$ $\left.8.8 \mathrm{~Hz}, \mathrm{~J}_{2}=2.0 \mathrm{~Hz}\right), 3.03(\mathrm{~m}, 1 \mathrm{H}), 2.95(\mathrm{~m}, 1 \mathrm{H}), 2.87(\mathrm{~m}, 2 \mathrm{H}), 2.63$ (br. s, $\left.1 \mathrm{H}\right), 1.45\left(\mathrm{dt}, 1 \mathrm{H}, \mathrm{J}_{1}=\right.$ $\left.8.3 \mathrm{~Hz}, \mathrm{~J}_{2}=\mathrm{J}_{3}=1.6 \mathrm{~Hz}\right), 1.36(\mathrm{~d}, 1 \mathrm{H}, \mathrm{J}=8.3 \mathrm{~Hz}) ;{ }^{13} \mathrm{C}-\mathrm{NMR}\left(\mathrm{CDCl}_{3}, 100 \mathrm{MHz}\right), 134.7(\mathrm{CH}), 134.6$ $(\mathrm{CH}), 100.4(\mathrm{CH}), 69.3\left(\mathrm{CH}_{2}\right), 55.6(\mathrm{CH}), 51.9(\mathrm{CH}), 46.0(\mathrm{CH}), 45.9(\mathrm{CH}), 44.9(\mathrm{CH})$.

\section{4,6-Dioxa-5-phosphatricyclo[7.2.1.0 $\left.{ }^{2,8}\right]$ dodec-10-en-5-one (7a and 7b).}

A solution of diol 1 (50 mg, $0.32 \mathrm{mmol})$ and $\mathrm{PBr}_{3}(26 \mathrm{mg}, 0.96 \mathrm{mmol})$ in anhydrous ethyl ether (10 $\mathrm{mL}$ ) was kept under $\mathrm{N}_{2}$ atmosphere at $5^{\circ} \mathrm{C}$ for $45 \mathrm{~h}$. After quenching with chopped ice and extraction with ethyl ether, the organic phase was washed with water and saturated brine, and dried with $\mathrm{MgSO}_{4}$. The solvent was removed under vacuum to give $58 \mathrm{mg}(90 \%)$ of a mixture of isomers that were separated by chromatography in a silica gel column using a 3:7 mixture of hexane / ethyl acetate as eluent. Both isomers are white crystalline solids. Compound 7a: yield $29 \mathrm{mg}(45 \%)$; ${ }^{1} \mathrm{H}-\mathrm{NMR}$ $\left(\mathrm{CDCl}_{3}, 300 \mathrm{MHz}\right) \delta 6.71(\mathrm{~d}, 1 \mathrm{H}, \mathrm{J}[\mathrm{H}-\mathrm{P}]=725 \mathrm{~Hz}), 6.13$ (br. t, $\left.2 \mathrm{H}, \mathrm{J}=1.6 \mathrm{~Hz}\right), 4.16\left(\mathrm{dt}, 2 \mathrm{H}, \mathrm{J}_{1}=\mathrm{J}_{2}\right.$ $\left.=11.7 \mathrm{~Hz}, \mathrm{~J}_{3}[\mathrm{H}-\mathrm{P}]=9.3 \mathrm{~Hz}\right), 4.05\left(\mathrm{ddd}, 2 \mathrm{H}, \mathrm{J}_{1}=11.7 \mathrm{~Hz}, \mathrm{~J}_{2}[\mathrm{H}-\mathrm{P}]=20.4 \mathrm{~Hz}, \mathrm{~J}_{3}=3.6 \mathrm{~Hz}\right), 2.84(\mathrm{~m}, 2$ $\mathrm{H}), 2.81(\mathrm{~m}, 2 \mathrm{H}), 1.59\left(\mathrm{dt}, 1 \mathrm{H}, \mathrm{J}_{1}=8.5 \mathrm{~Hz}, \mathrm{~J}_{2}=\mathrm{J}_{3}=1.7 \mathrm{~Hz}\right), 1.53$ (br. d, $1 \mathrm{H}, \mathrm{J}=8.5 \mathrm{~Hz}$ ); ${ }^{13} \mathrm{C}-\mathrm{NMR}$ $\left(\mathrm{CDCl}_{3}, 75 \mathrm{MHz}\right) \delta 134.9(\mathrm{CH}), 66.0\left(\mathrm{CH}_{2}, \mathrm{~d}, \mathrm{~J}_{\mathrm{C}-\mathrm{P}}=6.9 \mathrm{~Hz}\right), 51.2\left(\mathrm{CH}_{2}\right), 45.7(\mathrm{CH}), 44.7(\mathrm{CH}) ;{ }^{31} \mathrm{P}-$ NMR $\left(\mathrm{CDCl}_{3}, 121.5 \mathrm{MHz}\right) \delta 10.77\left(\mathrm{dtt}, \mathrm{J}_{1}=\mathrm{J}_{2}=9.3 \mathrm{~Hz}, \mathrm{~J}_{3}=\mathrm{J}_{4}=20.6 \mathrm{~Hz}, \mathrm{~J}_{5}=725 \mathrm{~Hz}\right)$. Compound 7b: yield $29 \mathrm{mg}(45 \%){ }^{1} \mathrm{H}-\mathrm{NMR}\left(\mathrm{CDCl}_{3}, 300 \mathrm{MHz}\right) \delta 6.73(\mathrm{~d}, 1 \mathrm{H}, \mathrm{J}[\mathrm{H}-\mathrm{P}]=660 \mathrm{~Hz}), 6.13(\mathrm{t}, 2 \mathrm{H}, \mathrm{J}=$ $1.9 \mathrm{~Hz}), 4.14\left(\mathrm{ddd}, 2 \mathrm{H}, \mathrm{J}_{1}[\mathrm{H}-\mathrm{P}]=28.4 \mathrm{~Hz}, \mathrm{~J}_{2}=12.0 \mathrm{~Hz}, \mathrm{~J}_{3}=3.0 \mathrm{~Hz}\right), 3.68\left(\mathrm{dt}, 2 \mathrm{H}, \mathrm{J}_{1}=\mathrm{J}_{2}=12.0 \mathrm{~Hz}\right.$, $\left.\mathrm{J}_{3}[\mathrm{H}-\mathrm{P}]=10.7 \mathrm{~Hz}\right), 2.88(\mathrm{~m}, 2 \mathrm{H}), 2.83(\mathrm{~m}, 2 \mathrm{H}), 1.59\left(\mathrm{dt}, 1 \mathrm{H}, \mathrm{J}_{1}=8.5 \mathrm{~Hz}, \mathrm{~J}_{2}=\mathrm{J}_{3}=1.7 \mathrm{~Hz}\right), 1.50$ (br. 
$\mathrm{d}, 1 \mathrm{H}, \mathrm{J}=8.5 \mathrm{~Hz}) ;{ }^{13} \mathrm{C}-\mathrm{NMR}\left(\mathrm{CDCl}_{3}, 75 \mathrm{MHz}\right) \delta 135.0(\mathrm{CH}), 65.5\left(\mathrm{CH}_{2}, \mathrm{~d}, \mathrm{~J}\right.$-P $\left.=5.1 \mathrm{~Hz}\right), 50.6\left(\mathrm{CH}_{2}\right)$, $45.7(\mathrm{CH}), 42.8(\mathrm{CH}) ;{ }^{31} \mathrm{P}-\mathrm{NMR}\left(\mathrm{CDCl}_{3}, 121.5 \mathrm{MHz}\right) \delta 12.85\left(\mathrm{dtt}, \mathrm{J}_{1}=\mathrm{J}_{2}=10.5 \mathrm{~Hz}, \mathrm{~J}_{3}=\mathrm{J}_{4}=28.4 \mathrm{~Hz}\right.$, $\left.\mathrm{J}_{5}=660 \mathrm{~Hz}\right) ; \mathrm{IR}(\mathrm{KBr}) v_{\max } 2966,2389,1267,1047,797 \mathrm{~cm}^{-1}$.

\section{\{3-[(Methoxymethoxy)methyl]bicyclo[2.2.1]hept-5-en-2-yl\}methan-1-ol (8) and (methoxy-} methoxy)-\{3-[(methoxymethoxy)methyl]bicyclo[2.2.1]hept-5-en-2-yl\}methane (9).

To a suspension of $\mathrm{NaH}$ ( $29 \mathrm{mg}$ of a $60 \%$ suspension in mineral oil, corresponding to $1.2 \mathrm{mmol}$ ), previously washed with anhydrous hexane, in anhydrous THF $(10 \mathrm{~mL})$, maintained at $0^{\circ} \mathrm{C}$ under $\mathrm{N}_{2}$ atmosphere, was added a solution of diol $1(103 \mathrm{mg}, 0.66 \mathrm{mmol})$ in THF $(1 \mathrm{~mL})$. After $5 \mathrm{~min}$ the ice bath was removed and the reaction mixture was stirred for $1 \mathrm{~h}$. Chloromethyl methyl ether ( $80 \mathrm{mg}, 1.0$ mmol) was then added and the mixture was stirred for a further $1 \mathrm{~h}$ period. After quenching with chopped ice, the product was extracted with ethyl ether, the organic phase was dried with $\mathrm{MgSO}_{4}$ and the solvent was removed under vacuum. The crude product was purified by column chromatography in silica gel, using a 7:3 mixture of hexane and ethyl acetate as eluent. Compound 8: yield $88 \mathrm{mg}(67 \%)$; ${ }^{1} \mathrm{H}-\mathrm{NMR}\left(\mathrm{CDCl}_{3}, 300 \mathrm{MHz}\right) \delta 6.10\left(\mathrm{dd}, 1 \mathrm{H}, \mathrm{J}_{1}=5.5 \mathrm{~Hz}, \mathrm{~J}_{2}=2.6 \mathrm{~Hz}\right), 6.06\left(\mathrm{dd}, 1 \mathrm{H}, \mathrm{J}_{1}=5.5 \mathrm{~Hz}, \mathrm{~J}_{2}=\right.$ $2.6 \mathrm{~Hz}), 4.60(\mathrm{~s}, 2 \mathrm{H}), 3.42(\mathrm{~m}, 4 \mathrm{H}), 3.37(\mathrm{~s}, 3 \mathrm{H}), 2.85(\mathrm{~m}, 2 \mathrm{H}), 2.55(\mathrm{~m}, 2 \mathrm{H}), 1.45\left(\mathrm{dt}, 1 \mathrm{H}, \mathrm{J}_{1}=8.3 \mathrm{~Hz}\right.$, $\left.\mathrm{J}_{2}=\mathrm{J}_{3}=1.9 \mathrm{~Hz}\right), 1.37\left(\mathrm{dt}, 1 \mathrm{H}, \mathrm{J}_{1}=8.3 \mathrm{~Hz}, \mathrm{~J}_{2}=\mathrm{J}_{3}=1.5 \mathrm{~Hz}\right) ;{ }^{13} \mathrm{C}-\mathrm{NMR}\left(\mathrm{CDCl}_{3}, 75 \mathrm{MHz}\right) \delta 135.1$ $(\mathrm{CH}), 134.8(\mathrm{CH}), 96.6\left(\mathrm{CH}_{2}\right), 68.9\left(\mathrm{CH}_{2}\right), 63.0\left(\mathrm{CH}_{2}\right), 55.6\left(\mathrm{CH}_{3}\right), 49.7\left(\mathrm{CH}_{2}\right), 46.43(\mathrm{CH}), 46.38$ $(\mathrm{CH}), 45.4(\mathrm{CH}), 41.9(\mathrm{CH})$; IR (KBr) $v_{\max }$ 3421, 2934, 1383, 1157, 1111, $1045 \mathrm{~cm}^{-1}$. Compound 9: yield $1 \mathrm{mg}(<1 \%)$; this sample was identical (by $\left.{ }^{1} \mathrm{H}-\mathrm{NMR}\right)$ to other samples obtained in higher yields by other methods, from which come some of the spectral data that follow: ${ }^{1} \mathrm{H}-\mathrm{NMR}\left(\mathrm{CDCl}_{3}, 300\right.$ $\mathrm{MHz}) \delta 6.14(\mathrm{t}, 2 \mathrm{H}, \mathrm{J}=1.9 \mathrm{~Hz}), 4.58(\mathrm{~d}, 2 \mathrm{H}, \mathrm{J}=8.4 \mathrm{~Hz}), 4.56(\mathrm{~d}, 2 \mathrm{H}, \mathrm{J}=8.4 \mathrm{~Hz}), 3.38(\mathrm{~m}, 2 \mathrm{H}), 3.35$ $(\mathrm{s}, 6 \mathrm{H}), 3.13(\mathrm{t}, 2 \mathrm{H}, \mathrm{J}=9.1 \mathrm{~Hz}), 2.95(\mathrm{~m}, 2 \mathrm{H}), 2.48(\mathrm{~m}, 2 \mathrm{H}), 1.50\left(\mathrm{dt}, 1 \mathrm{H}, \mathrm{J}_{1}=8.3 \mathrm{~Hz}, \mathrm{~J}_{2}=\mathrm{J}_{3}=1.9\right.$ $\mathrm{Hz}), 1.35\left(\mathrm{dt}, 1 \mathrm{H}, \mathrm{J}_{1}=8.3 \mathrm{~Hz}, \mathrm{~J}_{2}=\mathrm{J}_{3}=1.5 \mathrm{~Hz}\right) ;{ }^{13} \mathrm{C}-\mathrm{NMR}\left(\mathrm{CDCl}_{3}, 75 \mathrm{MHz}\right) \delta 135.4(\mathrm{CH}), 96.5$ $\left(\mathrm{CH}_{2}\right), 67.9\left(\mathrm{CH}_{2}\right), 55.2\left(\mathrm{CH}_{3}\right), 49.0\left(\mathrm{CH}_{2}\right), 45.6(\mathrm{CH}), 41.5(\mathrm{CH})$; IR $(\mathrm{KBr}) v_{\max } 2991,1158,1111$, $1055 \mathrm{~cm}^{-1}$.

\section{3-[(Methoxymethoxy)methyl]bicyclo[2.2.1]hept-5-ene-2-carbaldehyde (10).}

To a solution of pyridinium dichromate $(113 \mathrm{mg}, 0.30 \mathrm{mmol})$ in anhydrous $\mathrm{CH}_{2} \mathrm{Cl}_{2}(3 \mathrm{~mL})$, maintained under $\mathrm{N}_{2}$ atmosphere, was added a solution of compound $\mathbf{8}$ (39 $\left.\mathrm{mg}, 0.19 \mathrm{mmol}\right)$ in $\mathrm{CH}_{2} \mathrm{Cl}_{2}$ ( $3 \mathrm{~mL}$ ). After stirring for $24 \mathrm{~h}$ at room temperature, the product was extracted and purified as described in experiment 1a. Yield $22 \mathrm{mg}(60 \%) .{ }^{1} \mathrm{H}-\mathrm{NMR} \delta\left(\mathrm{CDCl}_{3}, 300 \mathrm{MHz}\right) 9.41(\mathrm{~d}, 1 \mathrm{H}, \mathrm{J}=3.9$ $\mathrm{Hz}), 6.33\left(\mathrm{dd}, 1 \mathrm{H}, \mathrm{J}_{1}=5.7 \mathrm{~Hz}, \mathrm{~J}_{2}=2.7 \mathrm{~Hz}\right), 6.20\left(\mathrm{dd}, 1 \mathrm{H}, \mathrm{J}_{1}=5.7 \mathrm{~Hz}, \mathrm{~J}_{2}=3.0 \mathrm{~Hz}\right), 4.54(\mathrm{~s}, 3 \mathrm{H}), 3.38$ $(\mathrm{d}, 2 \mathrm{H}, \mathrm{J}=7.8 \mathrm{~Hz}), 3.32(\mathrm{~s}, 3 \mathrm{H}), 3.10(\mathrm{~m}, 1 \mathrm{H}), 3.01(\mathrm{~m}, 1 \mathrm{H}), 2.97(\mathrm{~m}, 1 \mathrm{H}), 2.83(\mathrm{~m}, 1 \mathrm{H}), 1.55(\mathrm{dt}, 1 \mathrm{H}$, $\left.\mathrm{J}_{1}=8.7 \mathrm{~Hz}, \mathrm{~J}_{2}=\mathrm{J}_{3}=2.0 \mathrm{~Hz}\right), 1.40\left(\mathrm{dt}, 1 \mathrm{H}, \mathrm{J}_{1}=8.7 \mathrm{~Hz}, \mathrm{~J}_{2}=\mathrm{J}_{3}=1.5 \mathrm{~Hz}\right) ;{ }^{13} \mathrm{C}-\mathrm{NMR} \delta\left(\mathrm{CDCl}_{3}, 75\right.$ MHz) $204.6(\mathrm{C}=\mathrm{O}), 135.03(\mathrm{CH}), 134.95(\mathrm{CH}), 96.1\left(\mathrm{CH}_{2}\right), 67.9\left(\mathrm{CH}_{2}\right), 54.9\left(\mathrm{CH}\right.$ or $\left.\mathrm{CH}_{3}\right), 54.3\left(\mathrm{CH}_{3}\right.$ or $\mathrm{CH}), 49.1\left(\mathrm{CH}_{2}\right), 45.7\left(\mathrm{CH}_{2}\right), 44.9(\mathrm{CH}), 44.8(\mathrm{CH})$; IR $(\mathrm{KBr}) v_{\max } 2935,2740,1713,1391 \mathrm{~cm}^{-1}$. 


\section{Methoxy[(3-vinylbicyclo[2.2.1]hept-5-en-2-yl)methoxy]methane (11)}

To a mixture of the phosphonium salt $\mathrm{Ph}_{3} \mathrm{PCH}_{3} \mathrm{Br}(207 \mathrm{mg}, 0.58 \mathrm{mmol})$ and THF $(5 \mathrm{~mL})$, cooled to $0^{\circ} \mathrm{C}$ under a $\mathrm{N}_{2}$ atmosphere, was added a solution of $n-\mathrm{BuLi}(0.35 \mathrm{~mL}$ of a $1.17 \mathrm{M}$ solution in hexane, $0.67 \mathrm{mmol})$. After stirring for $15 \mathrm{~min}$ at $0^{\circ} \mathrm{C}$, a solution of compound 10 (56 $\left.\mathrm{mg}, 0.29 \mathrm{mmol}\right)$ in THF $(1 \mathrm{~mL})$ was added. The ice bath was removed and the reaction mixture was stirred at room temperature for $22 \mathrm{~h}$. After quenching with chopped ice and extracting with ethyl ether, the resulting organic solution was washed with water and saturated brine, and dried with $\mathrm{MgSO}_{4}$. The solvent was removed under vacuum and the residue was purified by column chromatography (silica gel), eluting with a 7:3 mixture of hexane / ethyl acetate. Yield $43 \mathrm{mg}(77 \%) .{ }^{1} \mathrm{H}-\mathrm{NMR} \delta\left(\mathrm{CDCl}_{3}, 300 \mathrm{MHz}\right) 6.18$ $\left(\mathrm{t}, 2 \mathrm{H}, \mathrm{J}=1.1 \mathrm{~Hz}\right.$ ), $5.30\left(\mathrm{dt}, 1 \mathrm{H}, \mathrm{J}_{1}=16.9 \mathrm{~Hz}, \mathrm{~J}_{2}=\mathrm{J}_{3}=9.9 \mathrm{~Hz}\right.$ ), 5.07 (ddd, $1 \mathrm{H}, \mathrm{J}_{1}=16.9 \mathrm{~Hz}, \mathrm{~J}_{2}=2.5$ $\left.\mathrm{Hz}, \mathrm{J}_{3}=0.6 \mathrm{~Hz}\right), 4.90\left(\mathrm{ddd}, 1 \mathrm{H}, \mathrm{J}_{1}=9.9 \mathrm{~Hz}, \mathrm{~J}_{2}=2.6 \mathrm{~Hz}, \mathrm{~J}_{3}=0.4 \mathrm{~Hz}\right), 4.58(\mathrm{~d}, 1 \mathrm{H}, \mathrm{J}=6.4 \mathrm{~Hz}), 4.55(\mathrm{~d}$, $1 \mathrm{H}, \mathrm{J}=6.4 \mathrm{~Hz}), 3.34(\mathrm{~s}, 3 \mathrm{H}), 3.29\left(\mathrm{dd}, 1 \mathrm{H}, \mathrm{J}_{1}=9.6 \mathrm{~Hz}, \mathrm{~J}_{2}=5.6 \mathrm{~Hz}\right), 3.04\left(\mathrm{dd}, 1 \mathrm{H}, \mathrm{J}_{1}=9.6 \mathrm{~Hz}, \mathrm{~J}_{2}=\right.$ $10.5 \mathrm{~Hz}), 2.98(\mathrm{~m}, 1 \mathrm{H}), 2.86\left(\mathrm{dt}, 1 \mathrm{H}, \mathrm{J}_{1}=\mathrm{J}_{2}=9.9 \mathrm{~Hz}, \mathrm{~J}_{3}=3.4 \mathrm{~Hz}\right), 2.79(\mathrm{~m}, 1 \mathrm{H}), 2.46\left(\mathrm{dddd}, 1 \mathrm{H}, \mathrm{J}_{1}=\right.$ $\left.10.5 \mathrm{~Hz}, \mathrm{~J}_{2}=9.9 \mathrm{~Hz}, \mathrm{~J}_{3}=5.6 \mathrm{~Hz}, \mathrm{~J}_{4}=3.4 \mathrm{~Hz}\right), 1.49\left(\mathrm{dt}, 1 \mathrm{H}, \mathrm{J}_{1}=8.1 \mathrm{~Hz}, \mathrm{~J}_{2}=\mathrm{J}_{3}=1.5 \mathrm{~Hz}\right), 1.35(\mathrm{dt}, 1 \mathrm{H}$, $\left.\mathrm{J}_{1}=8.1 \mathrm{~Hz}, \mathrm{~J}_{2}=\mathrm{J}_{3}=1.5 \mathrm{~Hz}\right) ;{ }^{13} \mathrm{C}-\mathrm{NMR} \delta\left(\mathrm{CDCl}_{3}, 75 \mathrm{MHz}\right) 139.6(\mathrm{CH}), 135.8(\mathrm{CH}), 135.3(\mathrm{CH})$, $115.9\left(\mathrm{CH}_{2}\right), 96.5\left(\mathrm{CH}_{2}\right), 69.0\left(\mathrm{CH}_{2}\right), 55.1\left(\mathrm{CH}_{3}\right), 49.0\left(\mathrm{CH}_{2}\right), 48.2(\mathrm{CH}), 46.9(\mathrm{CH}), 45.2(\mathrm{CH}), 43.6$ $(\mathrm{CH}) ; \mathrm{IR}(\mathrm{KBr}) v_{\max } 2924,1634,1453,1151,1041,912,732 \mathrm{~cm}^{-1}$.

\section{(3-Vinylbicyclo[2.2.1]hept-5-en-2-yl)methan-1-ol (12).}

To a solution of compound $11(2.41 \mathrm{~g}, 12.4 \mathrm{mmol})$ in $\mathrm{MeOH}(70 \mathrm{~mL})$ were added a few drops of concentrated $\mathrm{HCl}$. The reaction mixture was heated to $60^{\circ} \mathrm{C}$ for $3 \mathrm{~h}$ (following the disappearance of the starting material by TLC) and then most of the $\mathrm{MeOH}$ was removed under vacuum. The product was extracted with ethyl ether, the organic solution was washed with $\mathrm{NaHCO}_{3}$ solution and dried with $\mathrm{MgSO}_{4}$. The solvent was removed under vacuum and the residue was purified by chromatography on a silica gel column, using a 7:3 mixture of hexane / ethyl acetate as eluent. Yield $1.10 \mathrm{~g}(59 \%) .{ }^{1} \mathrm{H}-$ NMR $\delta\left(\mathrm{CDCl}_{3}, 300 \mathrm{MHz}\right) 6.17(\mathrm{~m}, 2 \mathrm{H}), 5.34\left(\mathrm{dt}, 1 \mathrm{H}, \mathrm{J}_{1}=17.0 \mathrm{~Hz}, \mathrm{~J}_{2}=\mathrm{J}_{3}=10 \mathrm{~Hz}\right), 5.11\left(\mathrm{dd}, 1 \mathrm{H}, \mathrm{J}_{1}\right.$ $\left.=17.0 \mathrm{~Hz}, \mathrm{~J}_{2}=2.4 \mathrm{~Hz}\right), 4.94\left(\mathrm{dd}, 1 \mathrm{H}, \mathrm{J}_{1}=10 \mathrm{~Hz}, \mathrm{~J}_{2}=2.4 \mathrm{~Hz}\right), 3.37\left(\mathrm{dd}, 1 \mathrm{H}, \mathrm{J}_{1}=10 \mathrm{~Hz}, \mathrm{~J}_{2}=6.6 \mathrm{~Hz}\right)$, $3.15\left(\mathrm{dt}, 1 \mathrm{H}, \mathrm{J}_{1}=\mathrm{J}_{2}=10 \mathrm{~Hz}, \mathrm{~J}_{3}=3.5 \mathrm{~Hz}\right.$ ), 3.02 (br. s, $\left.1 \mathrm{H}\right), 2.94(\mathrm{~m}, 1 \mathrm{H}), 2.85\left(\mathrm{dt}, 1 \mathrm{H}, \mathrm{J}_{1}=\mathrm{J}_{2}=10 \mathrm{~Hz}\right.$, $\left.\mathrm{J}_{3}=3.4 \mathrm{~Hz}\right), 2.78(\mathrm{~m}, 1 \mathrm{H}), 2.40\left(\mathrm{ddt}, 1 \mathrm{H}, \mathrm{J}_{1}=\mathrm{J}_{2}=10 \mathrm{~Hz}, \mathrm{~J}_{3}=6.6 \mathrm{~Hz}, \mathrm{~J}_{4}=3.4 \mathrm{~Hz}\right), 1.49\left(\mathrm{dt}, 1 \mathrm{H}, \mathrm{J}_{1}=\right.$ $\left.8.4 \mathrm{~Hz}, \mathrm{~J}_{2}=\mathrm{J}_{3}=1.8 \mathrm{~Hz}\right), 1.35(\mathrm{~d}, 1 \mathrm{H}, \mathrm{J}=8.4 \mathrm{~Hz}) ;{ }^{13} \mathrm{C}-\mathrm{NMR} \delta\left(\mathrm{CDCl}_{3}, 75 \mathrm{MHz}\right) 139.9(\mathrm{CH}), 135.6$ $(\mathrm{CH}), 135.3(\mathrm{CH}), 116.1\left(\mathrm{CH}_{2}\right), 63.4\left(\mathrm{CH}_{2}\right), 49.4\left(\mathrm{CH}_{2}\right), 48.9(\mathrm{CH}), 46.8(\mathrm{CH}), 46.6(\mathrm{CH}), 44.9(\mathrm{CH})$; IR $(\mathrm{KBr}) v_{\max } 3329,2966,1636,1451,1342,910,732 \mathrm{~cm}^{-1}$. 
3-Vinylbicyclo[2.2.1]hept-5-ene-2-carbaldehyde (2a) and 4-Oxa-9-vinyltricyclo[4.2.1.0 $\left.{ }^{3,7}\right]$-nonan2-one (13)

To a solution of pyridinium dichromate $(230 \mathrm{mg}, 0.59 \mathrm{mmol})$ in anhydrous $\mathrm{CH}_{2} \mathrm{Cl}_{2}(4 \mathrm{~mL})$ maintained under $\mathrm{N}_{2}$ atmosphere, was added a solution of compound 12 (62 $\mathrm{mg}, 0.41 \mathrm{mmol}$ ) in $\mathrm{CH}_{2} \mathrm{Cl}_{2}(2 \mathrm{~mL})$. After stirring for $24 \mathrm{~h}$ at room temperature, the product was extracted and purified as described in experiment 1a, using a 7:3 mixture of hexane / ethyl acetate as eluent. Compound 2a: yield $35 \mathrm{mg}(57 \%) .{ }^{1} \mathrm{H}-\mathrm{NMR} \delta\left(\mathrm{CDCl}_{3}, 300 \mathrm{MHz}\right) 9.35(\mathrm{~d}, 1 \mathrm{H}, \mathrm{J}=3.4 \mathrm{~Hz}), 6.36\left(\mathrm{dd}, 1 \mathrm{H}, \mathrm{J}_{1}=5.9 \mathrm{~Hz}\right.$, $\left.\mathrm{J}_{2}=2.8 \mathrm{~Hz}\right), 6.24\left(\mathrm{dd}, 1 \mathrm{H}, \mathrm{J}_{1}=5.9 \mathrm{~Hz}, \mathrm{~J}_{2}=2.8 \mathrm{~Hz}\right), 5.41\left(\mathrm{dt}, 1 \mathrm{H}, \mathrm{J}_{1}=17.0 \mathrm{~Hz}, \mathrm{~J}_{2}=\mathrm{J}_{3}=10.0 \mathrm{~Hz}\right), 5.21$ $\left(\mathrm{ddd}, 1 \mathrm{H}, \mathrm{J}_{1}=17.0 \mathrm{~Hz}, \mathrm{~J}_{2}=2.0 \mathrm{~Hz}, \mathrm{~J}_{3}=0.6 \mathrm{~Hz}\right), 5.02\left(\mathrm{ddd}, 1 \mathrm{H}, \mathrm{J}_{1}=10.0 \mathrm{~Hz}, \mathrm{~J}_{2}=2.0 \mathrm{~Hz}, \mathrm{~J}_{3}=0.6 \mathrm{~Hz}\right.$ ), $3.24\left(\mathrm{dt}, 1 \mathrm{H}, \mathrm{J}_{1}=\mathrm{J}_{2}=10.0 \mathrm{~Hz}, \mathrm{~J}_{3}=3.4 \mathrm{~Hz}\right), 3.12(\mathrm{~m}, 1 \mathrm{H}), 3.02\left(\mathrm{dt}, 1 \mathrm{H}, \mathrm{J}_{1}=10.0 \mathrm{~Hz}, \mathrm{~J}_{2}=\mathrm{J}_{3}=3.4 \mathrm{~Hz}\right)$, $2.92(\mathrm{~m}, 1 \mathrm{H}), 1.54\left(\mathrm{dt}, 1 \mathrm{H}, \mathrm{J}_{1}=8.6 \mathrm{~Hz}, \mathrm{~J}_{2}=\mathrm{J}_{3}=1.9 \mathrm{~Hz}\right), 1.41(\mathrm{~m}, 1 \mathrm{H}) ;{ }^{13} \mathrm{C}-\mathrm{NMR} \delta\left(\mathrm{CDCl}_{3}, 75 \mathrm{MHz}\right)$ $205.5(\mathrm{C}=\mathrm{O}), 138.6(\mathrm{CH}), 135.9(\mathrm{CH}), 135.5(\mathrm{CH}), 117.0\left(\mathrm{CH}_{2}\right), 57.4(\mathrm{CH}), 49.4\left(\mathrm{CH}_{2}\right), 49.0(\mathrm{CH})$, $48.5(\mathrm{CH}), 45.4(\mathrm{CH})$; IR (KBr) $v_{\max } 2972,2729,1716,1636,1453,1392,912,737 \mathrm{~cm}^{-1}$. Compound 13: yield $3 \mathrm{mg}(5 \%)$. ${ }^{1} \mathrm{H}-\mathrm{NMR} \delta\left(\mathrm{CDCl}_{3}, 300 \mathrm{MHz}\right) 5.59\left(\mathrm{ddd}, 1 \mathrm{H}, \mathrm{J}_{1}=17.4, \mathrm{~J}_{2}=10.0 \mathrm{~Hz}, \mathrm{~J}_{3}=8.3\right.$ $\mathrm{Hz}), 5.19\left(\mathrm{ddd}, 1 \mathrm{H}, \mathrm{J}_{1}=17.4 \mathrm{~Hz}, \mathrm{~J}_{2}=1.5 \mathrm{~Hz}, \mathrm{~J}_{3}=1.0 \mathrm{~Hz}\right.$ ), $5.15\left(\mathrm{dd}, 1 \mathrm{H}, \mathrm{J}_{1}=10.0, \mathrm{~J}_{2}=1.5 \mathrm{~Hz}\right), 3.85$ (m, 3H), $3.09(\mathrm{~m}, 1 \mathrm{H}), 2.78(\mathrm{~m}, 2 \mathrm{H}), 2.47(\mathrm{~m}, 1 \mathrm{H}), 1.91(\mathrm{~d}, 1 \mathrm{H}, \mathrm{J}=11.5 \mathrm{~Hz}), 1.78(\mathrm{~d}, 1 \mathrm{H}, \mathrm{J}=11.5$ $\mathrm{Hz}) ;{ }^{13} \mathrm{C}-\mathrm{NMR}\left(\mathrm{CDCl}_{3}, 75 \mathrm{MHz}\right) \delta 211.9(\mathrm{C}=\mathrm{O}), 134.9(\mathrm{CH}), 118.3\left(\mathrm{CH}_{2}\right), 80.8(\mathrm{CH}), 70.4\left(\mathrm{CH}_{2}\right)$, $50.7(\mathrm{CH}), 44.6(\mathrm{CH}), 44.1(\mathrm{CH}), 41.2(\mathrm{CH}), 29.1\left(\mathrm{CH}_{2}\right)$; IR $(\mathrm{KBr}) v_{\max } 2974,1753,1639,1178,1129$, $1040 \mathrm{~cm}^{-1}$.

\section{References and Notes}

1. Wu, H. J.; C. Y. J. Org. Chem. 1999, 64, 1576-1584; in this paper the oxidation of a diol similar to 1 to a dihemiacetal with the Swern reagent is described. The dihemiacetal obtained has the same oxidation state of the dialdehyde, but is not an appropriate substrate for the Wittig reaction we intended to perform subsequently.

2. (a) Garrat, P. J. in Aromaticity, Wiley-Interscience, New York, 1986; Vogel, E.; Roth, H. D. Angew. Chem. Int. Ed. Engl. 1964, 3, 228; (b) Masamune, S.; Brooks, D. W. Tetrahedron Lett. 1977, 42, 3239-3240; (c) Scott, L. T.; Brunsvold, W. R. J. Amer. Chem. Soc., 1978, 100, 43204321.

3. (a) Fischer, N. H. Recent Advances in Phytochemistry 1991, 24, 161-201; (b) Minnaard, A. J.; Wijnberg, B. P. A.; de Groot, A. Tetrahedron 1999, 55, 2115-2146; (c) Vichnewski, W.; Takahashi, A. M.; Nasi, A. M. T. T.; Gonçalves, D. C. R. G.; Dias, D. A.; Lopes, J. N. C.; Goedken, V. L.; Gutiérrez, A. B.; Herz, W. Phytochemistry 1989, 28, 1441-1451.

4. Related previous works: (a) Constantino, M. G.; Beatriz, A.; da Silva, G. V. J. Tetrahedron Lett. 2000, 41, 7001-7004; (b) Constantino, M. G.; Beatriz, A.; da Silva, G. V. J.; Zukerman-Schpector, J. Synth. Commun., in press. 
5. (a) Culberson, C. F.; Seward, J. H.; Wilder Jr., P. J. Amer. Chem. Soc. 1960, 82, 2541-2547; (b) Lok, K. P.; Jakovac, I. J.; Jones, J. B. J. Amer. Chem. Soc. 1985, 107, 2521-2526.

6. Aït-Mohand, S.; Muzart, J. J. Mol. Catal. 1998, 129, 135-139.

7. Corey, E. J.; Palani, A. Tetrahedron Lett. 1995, 36, 3485-3488.

8. For instance: House, H. O. Modern Synthetic Reactions, $2^{\text {nd }}$ Edition, W. A. Benjamin, Inc.: Menlo Park, California, 1972.

9. (a) Silverstein, R. M.; Bassler, G. C.; Morril, T. C. Spectrometric Identification of Organic Compounds, $5^{\text {th }}$ Edition, John Wiley \& Sons, Inc.: New York, 1991; (b) Williams, D. H.; Fleming, I. Spectroscopic Methods in Organic Chemistry, McGraw-Hill: London, 1987.

10. (a) Breitmeier, E.; Voelter, W. Carbon-13 NMR Spectroscopy, $3^{\text {rd }}$ Edition, VCH: Weinheim, 1990;

(b) Wehrli, F. W.; Wirthlin, T. Interpretation of Carbon-13 NMR Spectra, Heyden \& Son Ltd.: London, 1976.

11. (a) Setzer, W. N.; Brown, M. L.; Yang, X. J.; Thompsom, M. A.; Whitaker, K. W. J. Org. Chem. 1992, 57, 2812-2818; (b) Laurenti, D.; Feuerstein, M.; Pèpe, H. D.; Santelli, M. J. Org. Chem. 2001, 66, 1633-1637; (c) Harada, T.; Wada, I.; Oku, A. J. Org. Chem. 1989, 54, 2599-2605.

12. (a) Dess, D. B.; Martin, J. C. J. Amer. Chem. Soc. 1991, 113, 7277-7287; (b) Ireland, R. E.; Liu, L. J. Org. Chem. 1993, 58, 2899.

Sample availability: Samples of compounds $\mathbf{1}$ and $\mathbf{1 2}$ are available from MDPI.

(C) 2002 by MDPI (http://www.mdpi.org). Reproduction is permitted for noncommercial purposes. 